\title{
Field Emergence of shrunken-2 Corn Predicted by Single- and Multiple-vigor Laboratory Tests
}

\author{
Carlos A. Parera ${ }^{1}$, Daniel J. Cantliffe ${ }^{2}$, Peter J. Stoffella ${ }^{3}$, and Brian T. Scully ${ }^{4}$ \\ Horticultural Sciences Department, Institute of Food and Agricultural Sciences, Univ. of Florida, P.O. \\ Box 110690, Gainesville, FL 32611 \\ Additional index words. Zea mays, seed, germination, factor analysis, regression analysis
}

\begin{abstract}
Poor emergence and seedling vigor are common characteristics of many sweet corn (Zea mays L.) cultivars with the shrunken-2 (sh2) mutant endosperm. A rapid and reliable predictor of sweet corn seed field emergence would improve the potential for high quality crops. Field emergence of seven sh2 sweet corn cultivars grown at seven environments in Florida were correlated with laboratory vigor tests. Factor analysis was used to separate noncollinear vigor tests for subsequent multiple regression models. The best single predictor test $\left(R^{2}=0.93{ }^{* * t}\right)$ was an index based on leachate conductivity and germination percentage after a complex stress vigor test involving incubation at 15C. Leachate conductivity after $3 \mathrm{~h}$ soaking at 25 or $30 \mathrm{C}\left(R^{2}=0.9 \mathrm{~W}^{* * * *}\right)$, soil cold test $\left(R^{2}=0.9^{* * *}\right)$, alternate temperature stress conductivity test $\left(R^{2}=0.88^{* * * t}\right)$, standard germination test at $30 \mathrm{C}\left(R^{2}=0.88^{* * * *}\right)$, and an index involving incubation at $25 \mathrm{C}$ $\left(R^{2}=0.88^{*+*}\right)$ were also good predictors of field emergence. Noncollinear tests including the towel germination test at 25 $\mathrm{C}$ and an alternate temperature stress conductivity test resulted in the best two factor predictor $\left(r^{2}=0.89^{* * * *}\right)$, and with glutamic acid decarboxylase activity (GADA) was the best three factor predictor $\left(r^{2}=0.93\right.$ (***). The index of conductivity and complex vigor test (ICS) evaluated seed membrane integrity and potential for pathogen infection, respectively, and can be considered as major factors affecting emergence in $s h 2$ sweet corn.
\end{abstract}

Poor seed emergence and vigor in sweet corn with the shrunken$2(s h 2)$ gene has been attributed to a dysfunction of carbohydrate utilization in the scutellum (Styer and Cantliffe, 1984), susceptibility to seed and soil-borne diseases (Berger and Wolf, 1974), and potential imbibitional injury affecting membrane integrity (Chem and Sung, 1991; Parera and Cantliffe, 1991).

High-quality seeds are essential to achieve optimum plant populations and crop stand uniformity. Both are primary factors affecting crop yield and quality in single harvest sweet corn operations. The standard (towel) germination test is poorly correlated with field emergence in some species (Perry, 1978). Perry (198 1) reported that vigor tests represented seed field performance more adequately than germination tests. Attempts have been made to develop a standardized vigor test to predict field emergence for various species. However, to date only the conductivity test for one species, garden peas (Pisum sativum L.), is internationally accepted as an indicator of seed vigor (Hampton and Coolbear, 1990).

An ideal vigor test must be repeatable, rapid and inexpensive, and able to reflect the potential of the seed lot under unfavorable and favorable conditions (Matthews, 1981). The soil cold test is reported to estimate seed vigor in corn [Association of Official Seed Analysts (AOSA), 1983]. Stress conditions such as low temperature and high soil moisture content under laboratory conditions correlates with field emergence of corn (Martin et al., 1988), however, contradictory results were reported by Fiala

Received for publication 6 May 1994. Accepted for publication 8 Aug. 1994. Florida Agricultural Experiment Station Journal series no. R-02545. We express ourappreciationto R. Littell for assistance with statistical analyses and to Asgrow SeedCo.and Crookham Seed Co. for supplying the seed used in this investigation. The cost of publishing this paper was defrayed in part by the payment of page charges. Under postal regulations, this paper therefore must be hereby marked advertisement solelyto indicate this fact.

'Former graduate student.

${ }^{2}$ Professor and chairman.

${ }^{3}$ Professor,AgriculturalResearchandEducationCenter,P.O.Box248, Fort Pierce, FL 34954.

${ }^{4}$ Associateprofessor, Everglades Research and Education Center, P.O. Box 8003, Belle Glade, FL 33430
(1987). The cold test has produced variable results in corn among different laboratories (Burris and Navratil, 1979).

Biochemical activity of the seed may also predict seedling performance (Perl, 1987). The conductivity testis a biochemical test recommended by AOSA (1983) as another indicator of corn seed vigor. This test is rapid in that the seeds are soaked and the electric conductivity of the leachate is measured after a short time. Negative correlations between the conductivity test and field emergence of sugary $(s u)$ and $s h 2$ sweet corn have been reported in soils with temperatures below 20C (Waters and Blanchette, 1983; Tracy and Juvik, 1988). Activity of glutamic acid decarboxylase has also been correlated with seed vigor (Grabe, 1964) or seed deterioration in corn (Bautista and Linko, 1962).

The complex stress vigor test was reported to be a successful laboratory test for predicting field emergence in wheat (Triticum aestivum L.) and field corn (Barla-Szabo and Dolinka, 1988). The test is divided into a stress period, $24 \mathrm{~h}$ soaking at $25 \mathrm{C}$ and $24 \mathrm{~h}$ at $5 \mathrm{C}$, followed by germination in rolled paper towel at $25 \mathrm{C}$. The accelerated aging test is another approach proposed to predict field emergence. The test has wide acceptance for evaluating seed quality of soybean (Glycine $\max$ L.) (TeKrony, 1973). Repeatability problems of the accelerated aging test have been reported in $\operatorname{sh} 2$ sweet corn (Wilson and Trawatha, 1991) and other species (Perry, 1984). In a preliminary experiment, sh 2 sweet corn seeds were severely infected by pathogens during high humidity storage, thereby producing misleading field emergence results.

Our objective was to evaluate reliable, rapid, and inexpensive laboratory tests to predict the field emergence and vigor of $\operatorname{sh} 2$ sweet corn seed sown in diverse environments.

\section{Materials and Methods}

Six sh2 sweet corn cultivars consisting of a total of 14 variations in seed size or lot number were used: 'Sweet Belle' (seed size F32/ F40), 'Even Sweeter' (F32/F40/F40), 'Dazzle' (F32/F40/F32/ F40), and 'Challenger' (F32/F40/F40) (Asgrow Seed Co.), 'How Sweet It Is' and 'CrispN'Sweet711' (Crookham Seed Co.), and a breeding line consisting of two lots and two seed sizes XPH-3009 
(F32/F40/F40/F40) (Asgrow Seed Co.) were used in this study. The untreated seeds were stored at $10 \mathrm{C}$ and $45 \%$ relative humidity $(\mathrm{RH})$ during the experiment.

\section{Laboratory vigor tests}

Bulk conductivity tests. Twenty seeds were soaked in $25 \mathrm{ml}$ of distilled water at 15 (C 15/3), 25 (C25/3), and 30C (C30/3). The electrical conductivity of the leachate was measured hourly for 24 $\mathrm{h}$ with a conductivity meter (Lecto Mho-meter, Lab-Line Instruments, Melrose Park, Ill.) and expressed as $\mu \mathrm{mhos} \cdot \mathrm{g}^{-1}$ of seed. Conductivity measured after $3 \mathrm{~h}$ soaking was used in the correlation analyses.

Alternate stress temperature conductivity test. Electrical conductivity of the leachate was measured as described in the bulk conductivity test, after the seeds were soaked at 5 and $30 \mathrm{C}$ for $3 \mathrm{~h}$, then transferred to $30(\mathrm{C} 5 / 30 / 6)$ and $5 \mathrm{C}(\mathrm{C} 30 / 5 / 6)$, respectively, for an additional $3 \mathrm{~h}$. Means for the initial 3-h soak and the final 6$\mathrm{h}$ soak conductivity were calculated for treatments 5/30C (AC5/ 30) and 30/5C (AC30/5), respectively.

Embryo conductivity. Intact embryos (axis plus scutellum) were removed from seeds after incubation for 4 days at $100 \% \mathrm{RH}$ and $15 \mathrm{C}$ to soften the tissue and avoid embryo damage (Bruggink et al., 1991). The excised embryos were dried at 30C for 3 days and soaked (10 embryos) in $25 \mathrm{ml}$ distilled water at $25 \mathrm{C}$. Electrical conductivity was recorded hourly for $24 \mathrm{~h}$ ( $\mu \mathrm{mhos} \cdot \mathrm{g}^{-1}$ of embryo). The conductivity of the leachate at 3 (EC3) and 6 h (EC6) was used for the correlation analyses.

Cold germination test. The test was performed according to AOSA (1983) procedures. Fifty seeds were sown in a plastic box $(25 \times 25 \times 10 \mathrm{~cm})$, filled $2.5 \mathrm{~cm}$ deep with compacted Arredondo fine sandy soil (loamy, silaceous, hyperthermic Grossarenic Palenundult) (GCTS) or Terra-Lite vermiculite (Grace and Co., Cambridge, Mass.) (GCTV). Another 2.5-cm layer of the substrate was placed on top of the seeds. The media were adjusted to $70 \%$ of water-holding capacity, sealed, incubated at 10C for 7 days, then transferred to $25 \mathrm{C}$ for 4 days. Seedlings with leaves $2 \mathrm{~mm}$ in length above the soil were considered emerged and total emergence calculated.

Standard germination tests. The test was performed according to AOSA ( 1983) procedures. Twenty-five seeds were placed on 3 layers of moist, nontoxic, germination paper (Anchor Paper Co., St. Paul, Minn.). The papers were rolled, placed in a plastic container $(21.5 \mathrm{x}$ $32.5 \times 5.5 \mathrm{~cm}$ ), and incubated in a dark germinator at 15 (GR 15), 25 (GR25), and 30C (GR30) for 7 days. Dry weights of shoots and roots (DW15, DW25, and DW30) were then recorded.

Complex stress vigor test. Two hundred seeds were soaked 24 $\mathrm{h}$ in $250 \mathrm{ml}$ of distilled water at $25 \mathrm{C}$ then transferred to $5 \mathrm{C}$ for an additional $24 \mathrm{~h}$ (Barla-Szabo and Dolinka, 1988). After soaking, the rolled towel test was performed, where the seeds were placed on a rolled towel as described above with the radicle pointing downward, placed in a germination chamber and incubated for 96 $\mathrm{hr}$ at $15(\mathrm{ST} 25 / 5 / 15), 25(\mathrm{ST} 25 / 5 / 25), 30 \mathrm{C}(\mathrm{ST} 25 / 5 / 30)$. A 25 or $30 \mathrm{C}$ soaking temperature combination was also used with the same range of incubation temperatures (ST25/30/1 5, ST25/30/25, and ST25/30/30). The conductivity of the leachate after each soaking period was measured as described in the bulk conductivity test. An index of conductivity $\mathrm{y}$ for complex stressing vigor test (ICS) was calculated as

$\mathrm{ICS}=1 / \mathrm{AVC} \times \mathrm{G}$

where AVC is the mean conductivity between the two soaking periods expressed in $\mu \mathrm{mhos} \cdot \mathrm{g}^{-1}$ seed, and $\mathrm{G}$ is the final germination percentage of the rolled towel test. ICS was calculated for each complex stressing test described above and identified as: ICS25/5/
30, ICS25/5J25, ICS25/5/15, ICS25130130, ICS25/30/25, and ICS25/30/15.

Glutamic acid decarboxylase activity test (GADA). GADA was measured with a Gilson differential respirometer (Gilson Medical Electronics, Middleton, Wis.) at $25 \mathrm{C}$ and expressed in $\mu \mathrm{l} \mathrm{CO}_{2} / \mathrm{g}$. Seeds $(5 \mathrm{~g})$ were ground in a grinder (Virtis Co., Gardiner, N. Y.) at high speed for $2 \mathrm{~min}$. In a reaction flask, $1 \mathrm{~g}$ of the ground seed was mixed with $2.5 \mathrm{ml}$ of $0.1 \mathrm{M}$ glutamic acid in $0.067 \mathrm{M}$ phosphate buffer at $5.8 \mathrm{pH}$ (Ram and Wiesner, 1988). The flasks were incubated at $25 \mathrm{C}$ in a water bath and agitated at 100 oscillations/rein. After $10 \mathrm{~min}$ stabilization, the $\mathrm{CO}_{2}$ production was measured for $10 \mathrm{~min}$.

Field evaluation. Field trials were established at the Univ. of Florida Horticultural Unit, Gainesville, on an Arredondo fine sand soil (loamy, silaceous, hyperthermic Grossarenic Palenundult), the Agricultural Research and Education Center, Fort Pierce, on an Oldsmar fine sand soil (sandy, siliceous, hyperthermic Alfic Arensic Haplaquods), and the Everglades Research and Education Center, Belle Glade, on a Pahokee Muck (evic, hyperthermic Lithic Medisaprist). Plot size, fertilization, irrigation system, planting dates, and mean temperatures for each site are described in Table 1. Fifty seeds were seeded $4 \mathrm{~cm}$ deep-in two rows per plot. Emergence rate index (ERI) (Shmueli and Goldberg, 1971) and emergence percentage were calculated for each plot.

Statistical analyses. Laboratory and field emergence experiments were conducted as randomized complete block designs, with each treatment replicated four times. The SAS statistical package (SAS Institute, Cary, N. C.) was used for data analyses. The seed size $\times$ cultivar interaction for field emergence and ERI were not significanq therefore, seed sizes were averaged for each genotype. Percentage data were transformed using arcsine and subjected to combined analyses of variance with environments as main blocks and genotypes as split plots. Correlation coefficients $(r)$ between laboratory tests with field emergence and ERI were determined. Simple linear regression analyses were used to select the best single vigor test that predicted field emergence. Multivariate factor analysis was used to separate independent, noncollinear vigor tests that were subsequently used in multiple-regression models (Steiner et al., 1989). The variables were rotated using the varimax orthogonal rotation (Delis and Adams, 1978). Multiple stepwise regression procedure was used to determine which multiple tests best predicted field emergence.

Table 1. Sowing date, soil type, bed size, fertilization, irrigation system, and mean temperature for each location used in the study.

\begin{tabular}{|c|c|c|c|}
\hline & \multicolumn{3}{|c|}{ Location } \\
\hline & Gainesville & Fort Pierce & Belle Glade \\
\hline Soil type & Sandy & Sandy & Muck \\
\hline \multicolumn{4}{|l|}{ Bed size (m) } \\
\hline Length & 7.6 & 7.6 & 7.6 \\
\hline Width & 1.2 & 2.1 & 0.7 \\
\hline Apart & 0.7 & 1.1 & 0.5 \\
\hline \multicolumn{4}{|l|}{ Fertilizer $\left(\mathrm{kg} \cdot \mathrm{ha}^{-1}\right)$} \\
\hline $\mathrm{N}$ & 180 & 153 & 0 \\
\hline $\mathrm{P}$ & 60 & 67 & 97 \\
\hline K & 180 & 127 & 0 \\
\hline Irrigation $^{2}$ & OS & SS & SS \\
\hline Sowing dates/temp $\left({ }^{\circ} \mathrm{C}\right)^{y} 28$ & $\begin{array}{l}8 \mathrm{March} / 21.3 \\
18 \mathrm{Apr} . / 23.5 \\
3 \text { Dec./13.1 }\end{array}$ & $\begin{array}{ll}4 & \text { Apr./23.8 } \\
3 & \text { Dec./1 } 9.7\end{array}$ & $\begin{array}{cc}9 & \text { Sept./26.1 } \\
18 & \text { Dec./21.6 }\end{array}$ \\
\hline
\end{tabular}

${ }^{2} \mathrm{OS}=$ overhead sprinkler, $\mathrm{SS}=$ subsurface.

${ }^{y}$ Mean air temperature of the first 10 days after sowing. 


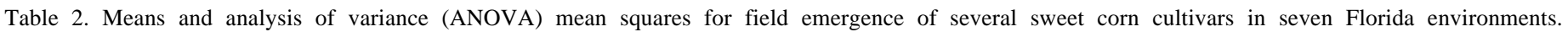

\begin{tabular}{|c|c|c|c|c|c|c|c|}
\hline \multirow[b]{3}{*}{ Genotype } & \multicolumn{7}{|c|}{ Location } \\
\hline & \multicolumn{3}{|c|}{ Gainesville } & \multicolumn{2}{|c|}{ Fort Pierce } & \multicolumn{2}{|c|}{ Belle Glade } \\
\hline & 28 Mar. & 18 Apr. & 3 Dec. & 4 Apr. & 3 Dec. & 9 Sept. & 18 Dec. \\
\hline \multicolumn{8}{|c|}{ Emergence(\%) } \\
\hline Sweet Belle & 82 & 84 & 76 & 62 & 73 & 83 & 84 \\
\hline Even Sweeter & 38 & 43 & 54 & 18 & 32 & 15 & 39 \\
\hline Dazzle & 35 & 49 & 12 & 35 & 40 & 35 & 54 \\
\hline ХРН-3009 & 26 & 42 & 12 & 27 & 22 & 24 & 41 \\
\hline Challenger & 74 & 78 & 64 & 50 & 55 & 84 & 79 \\
\hline How Sweet It Is & 25 & 46 & 7 & 38 & 33 & 16 & 36 \\
\hline Crisp N' Sweet & 89 & 89 & 72 & 85 & 70 & 92 & 91 \\
\hline Source & $\mathrm{df}$ & $\mathrm{MS}^{\mathrm{z}}$ & $\mathrm{F}$ & & & & \\
\hline Environment (E) & 6 & 0.3555 & $8.05^{* * *}$ & & & & \\
\hline Error a (Rep/E) & 21 & 0.0441 & & & & & \\
\hline Genotype (G) & 6 & 2.3207 & $346.33^{* * *}$ & & & & \\
\hline $\mathrm{G} \times \mathrm{E}$ & 36 & 0.0397 & $53.06^{* 8 s}$ & & & & \\
\hline Error $b$ & 126 & 0.0067 & & & & & \\
\hline Total & 195 & & & & & & \\
\hline
\end{tabular}

${ }^{2}$ Based on arcsine-transformed data.

${ }^{* * *}$ Significant at $P \leq 0.001$.

\section{Results and Discussion}

Table 3. Simple linear correlation coefficients $(r)$ between laboratory vigor tests and seed field emergence and emergence rate index (ERI) of seven $\operatorname{sh} 2$ sweet corn cultivars.

\begin{tabular}{|c|c|c|}
\hline Test & Field emergence $^{z}$ & Emergencerate index ${ }^{z}$ \\
\hline \multicolumn{3}{|c|}{$r$} \\
\hline ICS25/5/15 & $0.97^{* *}$ & $0.97^{* *}$ \\
\hline $\mathrm{C} 25 / 3$ & $-0.95^{* *}$ & $-0.95^{* *}$ \\
\hline GCTS & $0.95^{* *}$ & $0.94^{* *}$ \\
\hline $\mathrm{AC} 30 / 5$ & $-0.94^{* *}$ & $-0.93^{* *}$ \\
\hline $\mathrm{C} 30 / 3$ & $-0.94^{* *}$ & $-0.93^{* *}$ \\
\hline GR30 & $0.94^{* *}$ & $0.93^{* *}$ \\
\hline ICS25/5/25 & $0.94^{* *}$ & $0.94^{* *}$ \\
\hline $\mathrm{C} 15 / 3$ & $-0.93^{* *}$ & $-0.93^{* *}$ \\
\hline $\mathrm{C} 30 / 5 / 6$ & $-0.93^{* *}$ & $-0.93^{* *}$ \\
\hline ICS $25 / 5 / 30$ & $0.91^{* *}$ & $0.92^{* *}$ \\
\hline $\mathrm{C} 5 / 30 / 6$ & $-0.90^{* *}$ & $-0.90^{* *}$ \\
\hline ST $25 / 5 / 30$ & $0.89^{* *}$ & $0.90^{* *}$ \\
\hline DW15 & $0.89^{* *}$ & $0.89^{* *}$ \\
\hline ICS25/30/25 & $0.88^{* *}$ & $0.87^{* *}$ \\
\hline $\mathrm{AC} 5 / 30$ & $-0.88^{* *}$ & $-0.87^{* *}$ \\
\hline ST25/5/15 & $0.88^{* *}$ & $0.88^{* *}$ \\
\hline $\mathrm{ST} 25 / 30 / 25$ & $0.87^{* *}$ & $0.85^{* *}$ \\
\hline $\mathrm{ST} 25 / 5 / 25$ & $0.86^{* *}$ & $0.87^{* *}$ \\
\hline GADA & $0.85^{* *}$ & $0.86^{* *}$ \\
\hline ICS $25 / 30 / 30$ & $0.85^{* *}$ & $0.83^{* *}$ \\
\hline DW25 & $0.84^{* *}$ & $0.82^{* *}$ \\
\hline GR25 & $0.84^{* *}$ & $0.83^{* *}$ \\
\hline ICS $25 / 30 / 15$ & $0.83^{* *}$ & $0.82^{* *}$ \\
\hline ST25/30/30 & $0.83^{* *}$ & $0.81^{* *}$ \\
\hline $\mathrm{ST} 25 / 30 / 15$ & $0.82^{* *}$ & $0.81^{* *}$ \\
\hline $\mathrm{EC} 3$ & $-0.82^{* *}$ & $-0.81^{* *}$ \\
\hline EC6 & $-0.81^{* *}$ & $-0.81^{* *}$ \\
\hline GR15 & $0.70^{* *}$ & $0.70^{* *}$ \\
\hline GCTV & $0.57^{*}$ & $0.57^{*}$ \\
\hline DW30 & $0.54^{*}$ & $0.53^{*}$ \\
\hline
\end{tabular}

${ }^{2}$ Data pooled over locations and planting dates.

${ }^{*}, * *$ Significant at $P=0.05$ or 0.01 , respectively.
High variability of field emergence (7\% to 92\%) occurred among genotypes and environments (Table 2). A wide range of environments were obtained when the temperatures (sowing date) and soil types of the environments were combined (Table 1). The seedling emergence percentage varied significantly among field locations. Genotypes $(G) \times$ environment $(E)$ interaction for field emergence percentage was significant. However, the sums of squares for $\mathrm{G} \times \mathrm{E}$ interaction represented only $6.9 \%$ of the total as compared with $74.7 \%$ for cultivar differences (Table 2). Therefore, correlation coefficients, factor analysis, and multiple regression analyses were performed on the pooled environmental means (seven planting date-location combinations).

Simple linear correlation coefficients $(r)$ between the laboratory vigor tests and field emergence and ERI ranged from 0.97 to 0.54 and 0.92 to 0.53 , respectively (Table 3 ). The index of conductivity and complex stressing vigor test (ICS25/5/15) (25/ 5C soaking time-15C incubation) had the highest correlation coefficient to field emergence $\left(r=0.97^{* *}\right)$ and ERI $\left(r=0.97^{* *}\right)$. The ICS test calculated when the incubation temperature was $25 \mathrm{C}$ (ICS25/5/25) was also a good predictor of field emergence and ER1 $\left(r=0.94^{* *}\right)$.

The performance of the conductivity tests was consistent with the results reported by Waters and Blanchette (1983) and Tracy and Juvik (1988). A higher negative correlation coefficient occurred when field emergence and ERI were correlated with bulk conductivity tests at $25 \mathrm{C}(\mathrm{C} 25 / 3)$ or $30 \mathrm{C}(\mathrm{C} 30 / 3)$ soaking temperature and alternate stress temperature conductivity test (AC30/5). The bulk conductivity test is a rapid and simple method to measure seed vigor by evaluating damage to seed coats and cell membranes. Several reports suggest that leachate electrical conductivity should beat least one of several variables to assess seed vigor (Loeffler et al., 1988; Tracy and Juvik, 1988).

The cold test was a good predictor of seedling emergence $(\boldsymbol{r}=$ $0.95 ")$ and ERI $\left(r=0.94^{* *}\right)$ when soil (GCTS) was used as a substrate. However, the cold test had the lowest correlation coefficient $\left(r=0.57^{*}\right)$ when vermiculite (GCTV) was the substrate, Fiala (1987) reported that seed quality and characteristics of the substrate (type, $\mathrm{pH}$, moisture content, and microorganism activity) 
Table 4. Factors originated after orthogonal rotation (varimax) from laboratory vigor tests to predict field emergence of sh2 sweet corn.

\begin{tabular}{|c|c|c|c|c|}
\hline \multirow[b]{2}{*}{ Vigor test } & \multicolumn{4}{|c|}{ Factors } \\
\hline & 1 & 2 & 3 & 4 \\
\hline $\mathrm{AC} 5 / 30$ & 0.78598 & & & \\
\hline GADA & -0.75394 & & & \\
\hline $\mathrm{C} 5 / 30 / 6$ & 0.78681 & -0.36709 & & \\
\hline $\mathrm{C} 30 / 5 / 6$ & 0.78037 & -0.44873 & & \\
\hline $\mathrm{AC} 30 / 5$ & 0.77238 & 4.44557 & & \\
\hline $\mathrm{C} 15 / 3$ & 0.72944 & 4.42072 & & \\
\hline GCTS & -0.64931 & 0.51921 & & \\
\hline ICS25/5/30 & -0.56658 & 0.67988 & & \\
\hline $\mathrm{ST} 25 / 5 / 30$ & -0.54300 & 0.60307 & & \\
\hline ICS25/5/25 & -0.51171 & 0.73505 & & \\
\hline ICS $25 / 30 / 25$ & -0.44635 & 0.76838 & & \\
\hline ST25/30/25 & -0.43615 & 0.72570 & & \\
\hline C3013 & 0.68593 & 4.40919 & -0.36821 & \\
\hline ICS25/5/15 & -0.62031 & 0.62875 & 0.37319 & \\
\hline $\mathrm{C} 25 / 3$ & 0.62599 & -0.44418 & -0.41942 & \\
\hline ST25/5/15 & -0.50956 & 0.48088 & 0.53403 & \\
\hline GR30 & -0.46855 & 0.46327 & $0.47-327$ & 0.36701 \\
\hline DW 15 & -0.61807 & & 0.36612 & \\
\hline EC6 & 0.50860 & & -0.72481 & \\
\hline EC3 & 0.48517 & & -0.74535 & \\
\hline DFV25 & -0.39829 & & & 0.66902 \\
\hline ICS25/30/30 & & 0.82848 & & \\
\hline ICS25/30/15 & & 0.80694 & & \\
\hline $\mathrm{ST} 25 / 30 / 30$ & & 0.78331 & & \\
\hline ST25/30/15 & & 0.76731 & & \\
\hline ST25/5/25 & 0.66831 & 0.48017 & & \\
\hline GR 15 & & & 0.85717 & \\
\hline GCTV & & & 0.83199 & \\
\hline GR25 & & & 0.72549 & \\
\hline DW30 & & & & 0.83605 \\
\hline Variation explained (\%) & 34.95 & 33.77 & 22.44 & 8.84 \\
\hline
\end{tabular}

greatly influence the results in the cold test. In our experiment, vermiculite exhibited a poor correlation with field emergence and ERI as compared to soil. The results confirm the potential difficulties with standardizing the cold test among laboratories as previously reported by Burris and Navratil (1979).

Multiple stepwise regression procedures have been used to combine two or more vigor tests to predict field emergence (Abdul-Baki and Anderson, 1973; Hall and Wiesner, 1990). In wheat, Steiner et al. (1989) reported a high collinearity y among laboratory vigor tests used to predict field emergence. The prediction of field emergence was not improved by adding a collinear test to the model, therefore a limited number of potential tests were available for use as a valid multiple regression model. In this experiment, four factors resulted from factor analysis (Table 4). The following independent (noncollinear) laboratory vigor tests were selected to calculate multiple linear regression models: AC5/ 30 and GADA (Factor 1); ICS25/30/30, ICS25/30/15, ST25/30/ 30, ST25/30/15 (Factor 2); GR15, GCTV, and GR25 (Factor 3); and DW30 (Factor 4). The best two-variable combination (test) included mean alternate stress temperature conductivity test (AC5/ 30) and standard (towel) germination test incubated at 25C (GR25) (Table 5). However, the coefficient of determination ( $\mathrm{R}^{\prime}$ ) was lower than the best single regression model, The best three variable (test) model equations incorporated AC53, GR25, and GADA, however, the $R^{2}\left(0.93^{* * *}\right)$ was equal to the best simple linear predictor. GADA has been reported as a good indicator of seed performance in corn (Grabe, 1964; Bautista and Linko, 1962); beans (Phaseolus vulgaris) (James, 1968), and wheat (Steiner et al., 1989).

The seed is a complex biological system where several factors such as genetic characteristics, seed and soil borne diseases, environmental conditions, and seed aging can affect vigor. The complex mechanism of germination includes a sequence of physical, biological, and biochemical components which coexist and interact. This complexity is practically impossible to explain by a single laboratory test. A single test may not predict the behavior of seeds under variable environmental conditions after sowing in the field. The combination of biochemical and physiological vigor tests has been proposed as a valid alternative to predict seed emergence (Ram and Wiesner, 1990; Hampton and Coolbear, 1990). The best single predictor of field emergence for sh 2 sweet corn in this experiment was an index where the conductivity of the leachate and germination under stress conditions were combined (ICS). Also, the best two noncollinear test included the conductivity of the leachate at stress temperatures (AC5/30) and a standard (towel) germination test at 25C (GR25).

The ICS proposed to estimate field emergence combines two main factors affecting seed emergence and seedling vigor of $s h 2$ sweet corn: the integrity of the membrane system of the seed and potential susceptibility to seed pathogens. The electrical conduc- 
Table 5. Best (higher $R^{2}$ ) one, two, and three noncollinear variable models for predicting field emergence by laboratory vigor tests in $\operatorname{sh} 2$ sweet corn.

\begin{tabular}{ll}
\hline \hline Regression model & $R^{2 z}$ \\
\hline $20.133+12.350$ ICS25/5/15 & 0.94 \\
$117.542-0.684$ C $25 / 3$ & 0.90 \\
$25.144+0.825$ GCTS & 0.90 \\
$105.305-0.439$ C $30 / 3$ & 0.88 \\
$15.970+0.744$ GR30 & 0.88 \\
$23.219+12.610$ ICS $25 / 5 / 25$ & 0.88 \\
$59.087-0.375$ AC5/30 +0.396 GR25 & 0.89 \\
$28.127-0.242$ AC5/30 +0.344 GR25 +0.1513 GADA & 0.93 \\
\hline
\end{tabular}

${ }^{2}$ All significant at $P \leq 0.001$.

tivity of the leachate considers the first factor. The germination percentage after the towel test at stress temperature may evaluate the tolerance of the seed and seedling to environmental stress and potential susceptibility to soil-borne pathogens.

The index of conductivity for the complex stress vigor test is nonsubjective, simple, and easy to standardize among laboratories as compared with other vigor tests recommended to evaluate field emergence of $\operatorname{sh} 2$ sweet corn.

\section{Literature Cited}

Abdul-Baki, A. and J.A. Anderson. 1973. Vigor determination in soybean seed by multiple criteria. Crop Sci. 13:630-632.

Association of Official Seed Analyst. 1983. Seed vigor testing. Handbook 32. Assn. Offic. Seed Anal., Springfield, 111.

Barla-Szabo, G. and B. Dolinka. 1988. Complex stressing vigor test: a new method for wheat and maize seeds. Seed Sci. Technol. 16:63-73.

Bautista, G.M. and P. Linko. 1962. Glutamic acid decarboxylase activity as a measure of damage in artificially dried and stored corn. Cereal Chem. 39:455-459.

Berger, R.D. and E.A. Wolf. 1974. Control of seedborne and soilborne mycoses of 'Florida Sweet' corn by seed treatment. Plant Dis. Rpt. 58:922-923.

Bruggink, H., H.L. Kraak, M. G.G.E. Dijkema, and J. Bekendam. 1991. Some factors influencing electrolyte leakage from maize (Zea mays L.) kernels. Seed Sci. Res. 1:15-20.

Burris, J.S. and R.J. Navratil. 1979. Relationship between laboratory coldtest methods and field emergence in maize inbreeds. Agron. J. 71:985988.

Chern, G.S. and F.J.M. Sung. 1991. Prevention of injury during imbibition in shrunken-2 corn seeds by osmotic control of water uptake. Seed Sci. Technol. 19:649-476.

Delis, J.C. and M.W. Adams. 1978. A factor analysis of plant variables related to yield in dry beans. I. Morphological traits. Crop Sci. 18:74-78.

Fiala, F. 1987. Report of the vigor test committee 1983-86. Seed Sci. Technol. 15:507-522.

Grabe, D.F. 1964. Glutamic acid decarboxylase activity as a measurement of seedling vigor. Proc. Assn. Offic. Anal. 54:100-105.

Hall, R.D. and L.E. Wiesner. 1990. Relationship between seed vigor tests and field performance of 'regar' meadow bromegrass. Crop Sci. 30:967970.

Hampton, J.G. and P. Coolbear. 1990. Potential versus actual seed
performance-Can vigor testing provide an answer? Seed Sci. Technol. $18: 215-228$.

James, E. 1968. Limitation of glutamic acid decarboxylase activity for estimating viability in beans. Crop Sci. 9:403-404.

Loeffler, T.M., D.M. TeKrony, and D.B. Egli. 1988. The bulk conductivity as an indicator of soybean seed quality. J. Seed Technol. 12:37-53.

Matthews, S. 1981. Evaluation of techniques for germination and vigor studies. Seed Sci. Technol. 9:543-551.

Martin, B. A., O.S. Smith, and M. O'Neil. 1988. Relationships between laboratory germination tests and field emergence in maize inbreeds. Crop Sci. 28:801-805.

Parera, C.A. and D.J. Cantliffe. 1991. Improved germination and modified imbibition of shrunken-2 sweet corn by seed disinfection and solid matrix priming. J. Amer. Soc. Hort. Sci. 116:942-945.

Perl, M. 1987. Review of biochemical approaches to rating seed vigor. Acts Hort. 215:55-60.

Perry, D.A. 1978. Report of the vigor test committee, 1974-1977. Seed Sci. Technol. 6:159-181.

Perry, D.A. 1981. Handbook of vigor test methods. Intl. Seed Testing Assn., Zurich, Switzerland.

Perry, D.A. 1984. Report of the vigor test committee, 1980-1983. Seed Sci. Technol. 12:301-308.

Ram, C. and E.E. Wiesner. 1988. Effect of artificial ageing on physiological and biochemical parameters of seed quality in wheat. Seed Sci. Technol. 16:579-587.

Shmueli, M. and D. Goldberg. 1971. Emergence, early growth, and salinity of five vegetable crops germinated by sprinkle and trickle irrigation in arid zones. HortScience 6:563-565.

Steiner, J.J., D.F. Grabe, and M. Tulo. 1989. Single and multiple vigor test for predicting seedling emergence of wheat. Crop Sci. 29:782-786.

Styer, R.C. and D.J. Cantliffe. 1984. Dependence of seed vigor during germination of carbohydrate source in endosperm mutant of maize. Plant Physiol. 76:196-200.

TeKrony, D.M. 1973. Seed vigor testing-1982. J. Seed Technol. 8:5560.

Tracy, W.F. and J.A. Juvik. 1988. Electrolyte leakage and seed quality in a shrunken-2 maize selected for improved field emergence. HortScience 23:391-392.

Waters, L. and B.L. Blanchette. 1983. Prediction of sweet corn field emergence by conductivity and cold tests. J. Amer. Soc. Hort. Sci. 108:778-781.

Wilson, D.O. and S.E. Trawatha. 1991. Physiological maturity and vigor in production of 'Florida Stay sweet' shrunken-2 sweet corn seed. Crop Sci. 31:1640-1647. 